\title{
Games of Belonging: Football, Boundaries and Politics between Germany and Turkey
}

\author{
Stefan Metzger ${ }^{1 \dagger}$ and Özgür Özvatan ${ }^{2 \star \dagger}$ \\ ${ }^{1}$ Otto Benecke Stiftung e.V., Bonn, Germany and ${ }^{2}$ Department of Social Sciences, Humboldt University of Berlin, Berlin, \\ Germany \\ ${ }^{\star}$ Corresponding author. Email: oezguer.oezvatan@hu-berlin.de \\ ${ }^{\dagger}$ These authors contributed equally to this manuscript and appear in alphabetical order.
}

\begin{abstract}
International football is a field for national identity performances in which narratives of national belonging are articulated. Games of belonging capture discourses on and debates over national belonging. Up-and-coming national football team diversity, and its public promotion, was expected to facilitate boundary blurring in the politics of belonging; however, it caused highly contentious debates revolving around the question of who belongs to Germany and Turkey and who does not. For this reason, we ask how (ethnoculturally) diverse national football teams challenge established narratives of national belonging and, thereby, trigger debates over national belonging across time and space. We compared the media discourse on national team diversity in Germany and Turkey with a special focus on players who disrupt conceptions of ethnic and cultural homogeneity, namely Mesut Özil and Nuri Şahin. Our study illustrates that upcoming international football events constitute games of belonging. Actors from the media, football associations, and politics largely demanded unilateral national belonging from the disrupters, Özil and Şahin. Both players' reactions, however, draw on conceptions of (trans-)national belonging which challenge and conflict with established narratives of (ethno-)national belonging.
\end{abstract}

Keywords: national identity; belonging; international football; migration; ethnicity; symbolic boundaries

International football generates a strong emotional response in terms of national belonging among spectators in stadiums, at home, or at public screening events. Especially at events such as the World Cup, national identity is performed by a selected group of sportspeople representing the whole nation-as well as by spectators performing this national identity.

In this article, we argue that international football is not only an arena for national identity performances, but also articulates, and to some extent challenges, narratives of national belonging. The title "games of belonging" captures this dimension of international sports, as national football team diversity is proclaimed to move beyond ethnic boundary-making, even though we witness "contentious games" where national belonging is (re-)negotiated.

In order to determine our research focus, we compare debates over (ethnically) diverse national teams from Germany and Turkey with a special focus on football players who disrupt ethnically homogeneous conceptions of national belonging, in our case Mesut Özil and Nuri Şahin. Although both players were born in Germany as (grand-)children of Turkish immigrants, Özil opted for the German national football team in 2009 while Şahin joined the Turkish one in 2005.

For this reason, we ask how national football-team diversity challenges narratives of national belonging and, thereby, triggers struggles over national belonging. Thus, we empirically investigate the

(C) Association for the Study of Nationalities 2020. This is an Open Access article, distributed under the terms of the Creative Commons Attribution licence (http://creativecommons.org/licenses/by/4.0/), which permits unrestricted re-use, distribution, and reproduction in any medium, provided the original work is properly cited. 
decade 2005-2015 in Germany and Turkey in order to explore (dis-)continuities in both nations' debates about belonging in international football. In those debates, we aim to cover the perspectives of mainstream media, public actors, national-team officials, and the aforementioned protagonists, Özil and Şahin, to the matter at hand, both cross-temporally and cross-nationally. In doing so, we seek to illuminate differences and similarities across time and space in what we call "games of belonging," which means debates over national belonging emerging in the field of international football. We argue that symbols of national-team diversification ("the protagonists") provoke conflicts over narratives of national belonging and, consequently, cause reflection on wider immigration-policy approaches.

This introduction is followed by framing the theoretical concepts guiding the empirical research. Further, we introduce the immigrant-integration approach and notion of belonging in both cases under scrutiny, Germany and Turkey. Then we present our methodological approach to this comparative case study. The results of our media discourse analysis are presented, ahead of their discussion in the context of each nation's wider immigrant integration and belonging approach in the closing section.

\section{Theoretical Framework}

We define the term "belonging" as "the subjective feeling of being at home in one's city, region or country, of easily moving through its particular places, and the sense of comfort and joy in inhabiting a particular locale" (Korteweg and Yurdakul 2014, 3; for a related definition see also Yuval-Davis 2011). This feeling, while primarily subjective on an individual level, can certainly apply to a group of subjects and even to an entire nation. Thus, national belonging describes the feeling of being at home in one's nation. It includes subjectivity; it is articulated and (re-)produced by different actors within a national public space. National belonging thus creates symbolic boundaries between insiders and outsiders (Bail 2008; Lamont and Molnar 2002). It is in these cultural practices that societies produce "cultural repertoires," or a set of ethnic, cultural, racial and religious narratives, which they can fall back on to make sense of certain events (Hall and Lamont 2013). History shows that boundaries of national belonging change over time (Eder 2006; Wimmer 2008a; Yurdakul 2009; for ethnic boundary drawing in German football, see Metzger 2018) and can be understood as permanent mutual ethnic closures, especially when it comes to "ethnic boundarymaking“ (Barth 1969; Wimmer 2008b) or a non-essentialist, fluid concept of drawing social boundaries (Alba 2005; Korteweg and Yurdakul 2009; 2014).

Nation-states were historically built on communities imagined to be homogeneous (Anderson 1991; Hobsbawm and Ranger 1992). However, societies and nation-states proved to be much more ethnically diverse than their narratives of (ethnic) homogeneity. In an increasingly globalized and interconnected modern world, international migration flows challenge static homogeneity conceptions (Castles and Miller 1998). This tension unleashes conflicts over mono- and multiethnic national belonging, which nourish fears of increasing immigration and diversity-and a supposed threat to national communities (see, for example, Huntington 2004).

Debates on national belonging can also be observed in sport, and in football in particular (Giulianotti 1999), especially with regard to national teams (for the German case, see Ismer 2011; Meier and Leinwather 2013). Even if enthusiasm for one's national team is not per se equal to proper nationalism (see, for example, Abell, Condor, Gibson, Lowe, and Stevenson 2007; Houlihan 1997), national teams are often still seen as representing the nation and thus trigger feelings of national identification (Markovits and Rensmann 2007). Such feelings stimulate rituals and collective emotions, hence creating intense feelings of belonging to a nation (Ismer 2011). In sum, they contribute to the construction of sameness based on an "imagined community" (Anderson 1991); in that sense, "an international football match involving our team intrudes into our daily routines, reminding us with whom we stand with regard to our fellow nationals and whom we stand against in the international sphere" (Sugden and Tomlinson 1998, 304). Ultimately, processes of social inclusion and exclusion are inherent to international sport and football. 
In recent decades, scholars have inaugurated thorough approaches to social, emotional, and cultural belonging going beyond national units, thus moving away from nationalism; while some have referred to cosmopolitanism (Beck and Grande 2007), others have talked about transnationalism (Faist 2000; Glick-Schiller, Basch, and Blanc-Szanton 1992; Soysal 2000). The concept investigated by Mandel (2008), "demotic cosmopolitanism," indicates how blurred the boundaries between cosmopolitanism and transnationalism are. In her research on German-Turkish challenges to citizenship and belonging in Germany, Mandel elucidates the transnational projections of German-Turkish immigrants and the way they create cosmopolitan projections in their everyday life experiences. However, Mandel's crucial insights into national belonging rely on experiences that occur in the private or, to some extent semi-public, space only. Instead, the theoretical approach inaugurated by Korteweg and Yurdakul (2014) covers the immigrant projection of national belonging in the public space, such as in media debates, thus depicting challenges to established narratives of national belonging. And yet there is hardly research on multiple and transnational projections of immigrants in public spaces (see for example Adamson 2001), particularly in cases where public immigrant actors perform national belonging in multiple national public spaces. These formerly bounded national spaces of communication have been transcended in recent decades (Sicakkan 2012). Therefore, we aim to analyze how Turkish German immigrant football players articulate their belonging to one (or more) collective(s) in a transnational space, that is, in their countries of both destiny (Germany) and origin (Turkey), and how this relates to the overall research question of how debates of national belonging evolve in international football.

We argue that conceptions of nationalism and transnationalism are per se inherent to debates on national football teams, particularly when national team officials, immigrant football players, and public actors in both Germany and Turkey engage in public debates on the subject of belonging to a national football team. In terms of case selection, Özil and Şahin were obvious choices, as their cases have been the most prominent and relevant in the last decade. Although both players were born in Germany, as children and grandchildren of Turkish immigrants, Özil opted for the German national football team in 2009, while Şahin joined the Turkish one in 2005. Given the fact that they are legally entitled to hold national citizenship of both countries, they are allowed to choose one national team until their first appearance for an adult national team (Huhn 2015). We argue that the choice of one national team challenges narratives of national belonging in both Germany and Turkey. As was the case with generation "black-blanc-bleur" of Zinedine Zidane, Lilian Thuram, and Youri Djorkaeff in France in 1998 (Boli, Gasaut, and Grognet 2010), national football team ethnoracial diversity caused nativist narratives of ethnocultural boundary-drawing 2008 to reverberate.

Our research began in Germany, a country that rejected immigration until the early 2000s. In 1995, Thränhardt characterized Germany as an "undeclared country of immigration," even if, in fact, Germany happened to be one of the most important immigration countries in the world (see also Martin 2004). Germany had been a country of immigration long before receiving Gastarbeiter ("guest-workers") in the 1950s. Before then, Germany faced vast immigration, from labor migrants from Silesia and East Prussia (now Poland) from the end of the 19th century onward to forced migration during and after the Second World War (Bade and Oltmer 2004). The country's historical past vis-à-vis migration and ethnic diversity was obviously repressed in Germany's collective memory for a long time, particularly with regard to the historical guilt over the Nazi era. The immigration reality was for a long time more or less denied by political elites (Faist and Triadafilopoulus 2006), and citizenship and national belonging in Germany followed an ethnocultural understanding (ius sanguini; see Brubaker 1992). It was only in 1999 that a more liberal citizenship regime with elements of ius soli was introduced (Brubaker 2010). In the following years, debates over national belonging oscillated between rather exclusionary rigid ethnocultural and rather inclusionary civic boundaries. These tension can especially be observed in debates over the football national team, most recently in 2016 when Alexander Gauland, one of the leaders of the right-populist party $\mathrm{AfD}$, provoked a media debate with his statement that people would like the 
black German football national team player Jerome Boateng (Ghanaian father, German mother) as a footballer, but not as a neighbor (see Özvatan and Forchtner 2019).

German sport and football tradition seem to have been characterized by identity politics since their beginnings (Meier and Leinwather 2013, 1204), from the nationalist Turner (gymnastic) movement in the 19th century to the "Nazi-Olympics" in 1936. And it was after the Second World War that the national football team played a major role in national identity formation, from the Fédération Internationale de Football Association (FIFA) World Cup in 1954, which "restored" national self-confidence, to the FIFA World Cup in 1990, celebrating German reunification. Until the end of the 1990s, migrant football players were rare in the national team. German football wassimilar to the postwar society_built on an imagined homogeneity (Blecking 2006; Huhn and Metzger 2016). Only when Chancellor Angela Merkel stepped into the dressing room of the German national team after a win against Turkey in order to shake Özil's hand in 2010 (see Figure 1) - and a photo of the scene was celebrated as late recognition of migrants and their descendants in Germany-did Germany seem to act symbolically as an immigration country.

Since the 1960s, Turkey has been an emigration country; it sends labor migrants to various industrialized countries, such as France, the Netherlands, and, in particular, Germany. The Turkish government depicts Turkish citizens living abroad as "ethnic Turks" and refers to them as its "diaspora." As such, they are also considered an important source of incoming financial transfers and are referred to as the Turkish political lobby abroad (Aydin 2014). From this perspective, one has to understand the dismissive reactions in Turkey to Özil's choice in 2009 as something of a disappointment and, in turn, a lack of recognition of the Turkish identity performed by the diaspora (Bora 2008). This is bound to a strongly romanticized sense of rigid ethnic nationalism in contemporary Turkey (see for example Altunışık and Tür 2005). Although Turkey is inhabited by roughly 50 different Muslim and non-Muslim ethnic groups, the Muslim Sunni Turks have been recognized as the "true" (secular) Turks defining Turkish national identity ever since the founding of the Turkish Republic in 1923 (Kaya 2014). Accordingly, Turkey pursued a republican path toward national belonging similar to the French model. That is, Turkey sought to homogenize its population by granting Turkish citizenship to all people living in Turkish territory, but it abstained

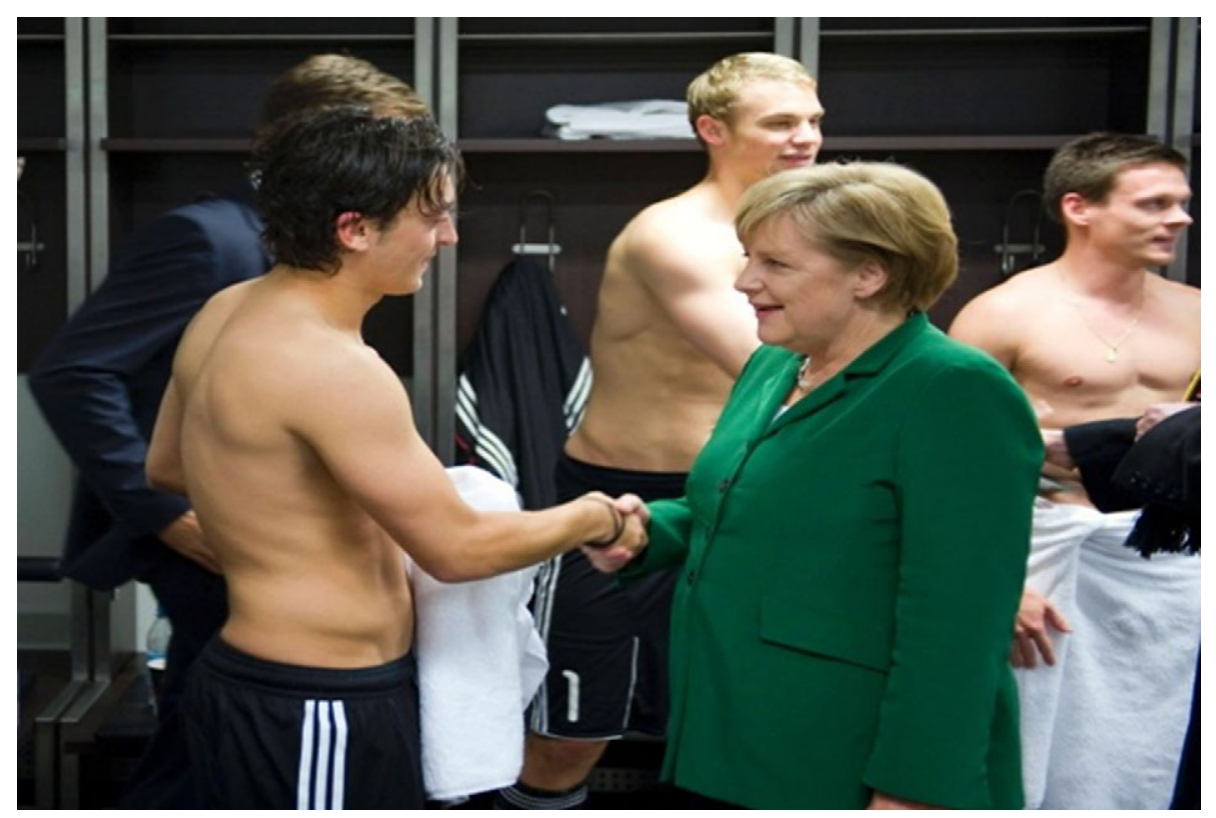

Figure 1. Mesut Özil shakes hands with German chancellor Angela Merkel in 2010 (Source: FAZ.net). 
from granting ethnic minorities particularistic group rights. In contemporary Turkey, we witness a conflict over the definition of nationhood between the newly power-ascending (neo-)Ottomanist notion and the ever-dominating secularist/anti-Ottomanist notion (Çınar and Taş 2017). Put together, the Turkish narrative of national belonging draws rigid boundaries between ethnic Muslim Sunni Turks and Turkey's others.

\section{Methodology}

In this article, we aim to explore how Özil's and Şahin's decisions to play for the German and Turkish national football teams are perceived and debated in the public spheres of both countries. Beside everyday-life discussions in the pub and at home watching football on TV, daily quality newspapers make up one of the major spheres where these international sport events are reported and talked about, and, most crucially, where "everyday nationhood" (Fox and Miller-Idriss 2008) is performed on a regular and emotional basis. In this study, we focus on German and Turkish newspaper articles between 2005 and 2015 in order to capture the debates that preceded and followed the decisions of both players to join one or other national football team.

To analyze how discourses over and narratives of belonging evolved over time, we collected data from the two mainstream newspapers with the largest readerships from Turkey, and one from Germany, in order to perform a media discourses analysis. The data we collected were analyzed drawing on the discourse historical approach (DHA) within critical discourse studies (CDS) (Wodak and Meyer 2009). For the German case, we gathered articles from the Frankfurter Allgemeine Zeitung (FAZ). The $F A Z$ is widely perceived as a centrist (i.e. centre-right) quality daily newspaper. It is also the second largest nationwide newspaper in Germany, with a print run of more than 260,000 in 2015. In the case of Turkey, our study relies on articles from the country's two leading daily newspapers, namely Zaman and Hürriyet. The former's circulation is the largest in Turkey, with an average of 650,000 daily quality newspapers distributed in 2015. Zaman is politically situated on the center-right as part of the so-called "modernist religious Gülen movement," which supported the governing Justice and Development Party (JDP) up until 2012, when the two sides broke ties with each other. ${ }^{1}$ Hürriyet, in turn, is perceived as a secularist and "Kemalist" centrist daily newspaper. An average of 350,000 copies of Hürriyet circulated daily in 2015. The daily newspapers we included were leading news outlets in both countries to the time of the analysis. Consequently, we analyzed them in order to depict the narratives of both societies' vast majorities.

Because of the event-based nature of sport and media reporting, we initially focused on work by Tilly (1995), who combines events and contentious debates in order to explain transactions across time and symbolic boundaries in a historical context. Later, Tilly shifted his event-based approach by introducing the concept of dynamics of contention, which revolve around these events. This concept comprises contentious episodes, which he defines as "bounded sequences of continuous interaction" (Tilly 2008, 10). His collaborator, Sidney Tarrow (2013), later further refined this conceptual framework and ended up with a theoretical concept, "streams of contention" 2013). According to Tarrow, contentious debates emerge in conjectural streams. In each stream, a complex network of interactional sociopolitical positioning may change due to the relational nature of political performances. In our work, we rely on the concept of streams of contention, as it not only offers a systematic approach to the discourse process, but also takes into account the context and in-depth content of debates, and thus reveals the trajectory of public actors' projections of (trans-)national belonging.

In our research practice, we first quantified the media articles collected in order to visualize the discourse process from 2005 onward (see Figure 2). The diagram in Figure 2 depicts salient time periods of national debates over belonging related to Özil and/or Şahin, and the German and/or Turkish national football teams. In those salient debates, we distinguished between three perspectives: football players, ${ }^{2}$ national team officials, and journalists. To make sense of these perspectives, we refer to Hall and Lamont's $(2013,56)$ concept of cultural repertoires, which they define as "sets of ideas, stories, discourses, frames, and beliefs that people draw on to create a line of action in the first place." 


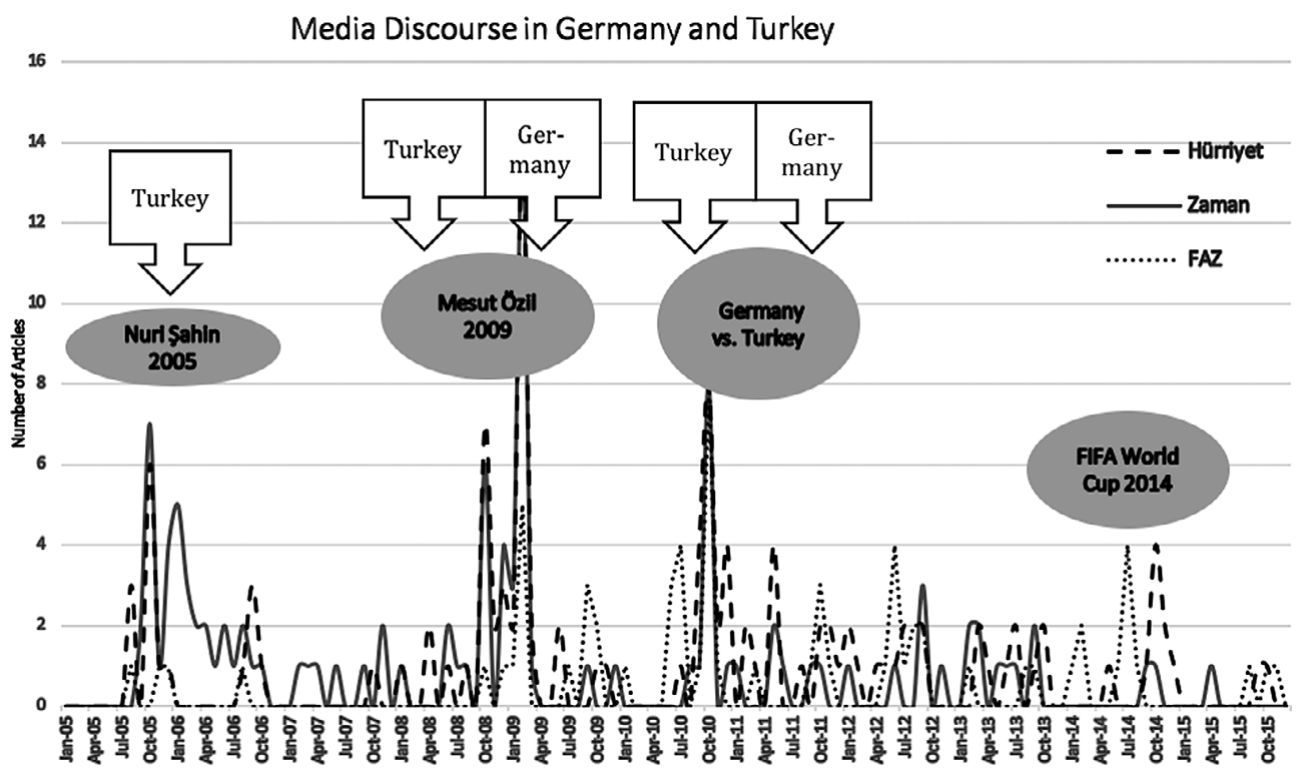

Figure 2. Media discourse process in Germany and Turkey. ${ }^{3}$ (source: authors's data)

We claim that the concept of cultural repertoires marks a well-suited tool to unfold the symbolic construction of (trans-)national belonging by public actors. Thus, we argue that the public actors under scrutiny draw on narratives embedded in cultural repertoires when they reiterate their statements, packaged as narratives, in public interaction with society, the media, and among each other.

We apply the DHA for two main reasons. The first, which also holds true for CDS in general, is that the DHA captures the interface of structure and agency, or, in other words, "discourse" in the DHA reveals that social performances are both socially constituted and socially constitutive (Wodak 2013) intertextuality and interdiscursivity. These techniques rely on in-depth qualitative knowledge and allow for cross-referencing across time and space in the data. However, as discourse measures agency (see definition above), we primarily understand interdiscursivity and intertextuality as how (1) discourse is inscribed in and interwoven with text (such as speeches, written texts, statements) and (2) inscription is transmitted across time and space. In the in-depth analysis part of streams of contention, and in the context of drawing inferences across streams, we rely strongly on these DHA criteria.

In the next section, we turn to the initial findings gathered using the aforementioned methods, analysis techniques, and theoretical concepts. First, we briefly describe the discourse process of debates of national belonging related to Şahin or Özil in Turkey and Germany. Then we turn to an analysis of evolving streams of contention.

\section{Empirical Results}

\section{Tracing Newspaper Discourse}

The newspaper discourse on Özil and Şahin in the last decade is mostly linked to the players' choices to play for either the German or the Turkish national football teams. Once they had opted for one team or the other, debates re-emerged during periods of international football events involving the national teams. Newspaper coverage of Özil and Şahin peaked when the two national teams played against each other. In total, we collected 236 media articles from Germany and Turkey. They are distributed as follows: 92 articles from the Turkish newspaper Hürriyet, 79 articles from Zaman, and 67 from the German newspaper Frankfurter Allgemeine Zeitung, from 2005 to 2015. 
Three major streams appeared in the time period under scrutiny. The first stream appeared when Sahin chose to play for the Turkish national team in the summer of 2005. The number of newspaper articles in Turkey increased, while debate in Germany was generally absent (Stream I). During the peak in October 2005, we counted 15 newspaper articles on Şahin's decision, eight in Hürriyet, and seven in Zaman. From July to October 2005, there were 24 newspaper articles in Turkey altogether, but only three in Germany. The most salient newspaper discussion-at least with regard to quantitystarted in October 2009, just before Özil's decision to play for the German national team (Stream II). From October 2008 to January 2009, numerous newspaper articles were published in Turkey and Germany. In January and February 2009 alone, there were 12 articles in Zaman, 10 in Hürriyet, and seven in Frankfurter Allgemeine Zeitung, all reporting on Özil's decision-making process. Thus, Özil's decision resulted in considerable attention from newspapers in both countries, while Şahin's decision was largely ignored in German newspapers. A third important stream (Stream III) emerged when both national teams met for a European championship qualifier match in October 2010, with both players on the pitch. In that month, 24 newspaper articles related to the investigated topic were published-eight articles in each of the newspapers under scrutiny. Those articles mainly focused on the upcoming match. This illustrates how Özil's and Şahin's decisions, as well as the match between the two national teams, generated tremendous public interest in both countries.

Next we conduct an in-depth analysis of the streams of contention that appeared in 2005, 2009, and 2010. We conduct subdivided discussions of the streams in 2009 and 2010, since those streams arose in the context of the same event but in different spatial contexts, one in the German public space and the other in the Turkish one.

\section{Media Discourse Analysis}

Stream I - "It Runs in the Blood," Nuri Şahin's Decision Covered in Turkey

The first debate related to Şahin in Turkish newspapers revolved around three issues: his emotional attachment to Turkey despite his socialization in Germany, his allegedly important role representing Turkey in Germany and Europe, and his decision to play for Turkey due to experiences of ethnic discrimination in Germany. In August 2005, Şahin became the youngest professional football player in the history of the German Bundesliga. Ever since, expected decision whether to play for either the German or the Turkish national team had been attracting attention from the media. His final decision can be interpreted as a decision influenced by his emotional attachment to Turkey, but also the ethnic discrimination against him from the German national team. The media constantly questioned the emotional reasoning behind his decision. In other words, it was of public interest to understand whether he felt more German or more Turkish. Two days after his first German Bundesliga match, he was quoted in Hürriyet as firmly claiming to be Turkish, and that he would remain so under any circumstances. Yet, in German football, we also find a strong narrative of structural ethnic discrimination against young Turkish football players (see Metzger 2018). The misrepresentation of Turkish immigrants on the German national football team is largely seen as being the result of ethnic discrimination against them. Turkey, or rather the Turkish Football Association, on the other hand, aimed to benefit from this narrative of structural discrimination by welcoming young Turkish football players from Germany onto the Turkish national team. Hence, the Turkish Football Association (TFF) established a recruitment office in Germany in 1998. This, however, does not necessarily mean that these young players are recognized as full members of Turkish society.

According to both newspaper commentaries and Şahin himself, Şahin's emotional attachment to Turkey is closely linked to the representative role he holds in Germany and Europe. He is described as a representative for Turkish football in the world, and for the Turkish nation and people in Germany. Confronted with detailed inquiries in the following weeks and months, he consistently responded that he views himself as a Turkish representative in Europe, which, again, implies that he sees himself as fully Turkish, pursuing a somewhat "Turkish mission" abroad. In the Turkish 
context, Şahin challenged a dominant notion of Turks born in Western Europe, the term gurbetçi. ${ }^{4}$ Şahin, the gurbetçi national team player, scored his first goal in his first match for the Turkish national team against Germany in October 2005, immediately after coming on as a substitute. Before and after the match, Zaman and Hürriyet published several articles pointing out that the so-called gurbetçi players would play a crucial role in an increasingly successful Turkish national football team in the future. Eventually, the debates in Turkey and the self-description of Sahin drew on an essentialist notion of ethnic Turkish identity based on blood and soil.

Stream II-Mesut Özil Challenges Clear-Cut Ethnic Boundaries: Media Discourse in Germany 2009 The debates in German newspapers over Özil's decision to play for the German national team in 2009 show some similarities to Şahin's decision in 2005. His decision was mainly illustrated from Özil's perspective. He was, like Şahin, repeatedly asked to express his emotional attachment to either Germany or Turkey. He further happened to be described as torn between the Turkish and German national teams, between different expectations, and between different (allegedly) homogeneous ethnonational cultures in general. Eventually, Özil did not tire of consistently emphasizing that he was not denying his ethnic Turkish roots by choosing the German national team.

Nevertheless, as we have seen in Şahin's case, Özil is also depicted as a representative and a role model for Turkish and other immigrants in Germany. In this context, it was reported in German media that, following his path, many Germans from a migrant background would increasingly identify with the German national team (FAZ, 11 July 2010). The German newspaper also printed an interview with an amateur football player in Germany with a Turkish background who supported the claim that Özil had also been a role model for him in identifying with Germany. Furthermore, $F A Z$ grasped the full, emotionally ambivalent response in German society by also giving voice to negative reactions to Özil's decision. One example is the coverage of Özil's homepage being briefly suspended immediately after his decision to play for the German national team had been announced. This was due to people of Turkish background labeling Özil a "traitor" who allegedly denied his "ethnic roots." In this stream, Özil apparently challenges an ethnic understanding of German and Turkish identity, which eventually reverberates with tensions between Turkish minorities and the host German society.

Stream II-Mesut Özil, "the Ethnic Traitor": Media Discourse in Turkey 2009

Turkish newspapers overwhelmingly covered Özil's case by focusing on how he would decide. After his successful performances in the Bundesliga, he became the rising star of that season. Consequently, he was treated as a candidate for both the German and the Turkish national football teams. After announcing he would play for the German national team, Özil was depicted as a role model for young people with a Turkish background in the German debate, whereas in the Turkish debate, he was called an "ethnic traitor." In the end, Özil justified his decision to play for Germany as a reward for the patient efforts of German officials.

The debate started in October 2008 and involved both national football team coaches, family members (his father and uncle), and Özil himself. Both coaches claimed that they were willing to wait for Özil to make this difficult decision. Over the course of the following weeks, the debate revolved, as in Şahin's case, around his emotional attachment to Germany and/or Turkey. Özil, however, struggled with having to choose one side, as he explained in Hürriyet (October 15, 2008): "I wish I had the option to play for both national football teams." In Germany, he expressed his emotional difficulty in abandoning the German national-team officials, as they had believed in him and had supported him for many years. The same day, his father and manager, Mustafa Özil, criticized the Turkish officials in charge for showing no interest in Mesut Özil in previous years. In the same vein, he praised the Germans for being very caring and argued that the German officials managed to arrange German citizenship for his son within just one week. A week later, Turkish newspapers cited a statement by Mesut Özil, published in a German football magazine, 
where he stated that he would very much appreciate a phone call from the German national coach (Zaman, October 21, 2008). Taking into account this obvious tendency toward Germany and Mustafa Özil's criticism of Turkish officials, the Turkish national coach resolutely expressed that he would not allow an 18-year-old football player to trade in the Turkish national jersey, its quality, and its precious honor (Hürriyet, November 6, 2008). In this conflict, the Turkish officials and media obviously expected an emotional response from Özil in favor of Turkey, who instead gave the impression that he would rationally weigh the facts and balance the pros and cons of the two sides.

His decision was made public in February 2009 by the German head coach, and this led to much contention, especially in the Turkish media. The immediate reaction of public anger from (German-)Turks to Özil's decision in favor of Germany was reported in both Germany and Turkey. This resulted in the suspension of Özil's personal website guest book due to numerous abusive comments. The core message of the comments, written in both Turkish and German, labeled Özil an "ethnic traitor" who was a bad role model for young Turkish people in Germany.

Özil himself entered the public debate, explaining that "German officials showed more interest in him." This remained his keynote, while in the following days he added that he felt Turkish and would remain so. He added that he would definitely not deny his Turkish background, but he was hoping that, after his decision, plenty of people from diverse ethnic, racial, and religious backgrounds would follow him by identifying with the German national football team. Furthermore, he stated that he had third-generation family and friends living in Germany and, as a consequence, he could feel at home in Germany, besides still feeling Turkish. He also claimed that, in sporting terms, his aim was to be a member of the German national football team for the 2010 World Cup in South Africa, which was, somehow, of less importance to the media at the time.

\section{Stream III-Germany versus Turkey in the European Championship Qualifiers: Media Discourse in Germany 2010}

A major debate in Germany and Turkey reached its climax when both countries met in the European Championship qualifiers in 2010. The game took place in the Berlin Olympic stadium, which was to a large share filled with Turkish immigrants living in Germany. For this match, both Özil and Şahin were on the field. In the weeks before the match, the debate in the German newspapers primarily stressed the emotional attachment of Özil and Şahin to one country or the other. In other words, this match turned out to be a "game of belonging" for both players. However, the public mono-national framing of this "game of belonging" obscured the actors' interpretations and feelings of belonging to more than a single nation.

One week before the actual event, German newspapers began to cover the match, starting with an interview with Şahin in which he was asked directly whether he felt Turkish. He replied that his parents were Turkish, which is why he would feel Turkish as well. He concluded by stating that he had always preferred to take the best from both cultures. The journalist showed particular interest in what, thinking back, Şahin would consider to be the right decision, his own or that of Özil, and what impact their decisions would have on young (immigrant) people in Germany. He simply stated that neither of the decisions should be subordinated to the other as wrong. Instead, one should recognize both decisions as legitimate and right. He added that people in Germany and Turkey should recognize that the next generation of young football players might pick either him or Özil as a role model when making their own choices. FAZ also printed a statement by Özil in the Turkish media where he asked Turkish people kindly not to label him a traitor if he scored against Turkey. The debate was then fueled by Hamit Altintop, another German-born player in the Turkish national team, who claimed that young football players should listen to their heart when choosing one side instead of exploiting this decision to advance their careers. Altintop abstained from referring to Özil when asking young players to make decisions based on emotionality rather than rationality when choosing a side. However, his statement could be, and partially was, interpreted as a critical reference to Özil, despite 
the fact that Altintop never mentioned Turkey with regard to "emotionality"; he merely mentioned that no matter what nation you choose, the decision should be led by emotionality.

After the match, newspapers in Germany focused on the binary portrayal of Turkish fans' emotional engagement with both Özil and Şahin during the match. Essentially, the former was booed while the latter enjoyed a warm welcome. However, Özil's handshake with chancellor Angela Merkel in the dressing room after Germany's win (see Figure 1) against Turkey indicates that Özil gained social recognition from the German side (here: German politics), while the Turkish side marked him as an ethnic traitor by booing him. According to the German editors of the $F A Z$, Merkel symbolically demonstrated the German government's sustainable and successful immigrant integration policies with this "snapshot." That is, Germany was evolving from having an ethnically fixed to an increasingly ethnically diverse narrative of national belonging.

\section{Stream III-Germany versus Turkey in the European Championship Qualifiers: Media Discourse in Turkey 2010}

The newspaper debate in Turkey used the event as an opportunity to focus on the decisions of both players to play for the respective national teams, particularly highlighting emotional expressions of belonging. In the Turkish papers, the attention revolved around public statements by Şahin and Özil. Zaman and Hürriyet pointed out the potential for conflict in the "game of belonging" for two reasons: (1) the comparably large numbers of gurbetçi players on both teams and (2) the 30,000 Turkish fans expected to attend the game at the Olympic Stadium in Berlin. Şahin expressed in several articles that this match was special to him, as there would be his ethnic home country on one side and the country he had been born in, and still lived in, on the other. Some weeks before the match, Şahin stated that he never regretted choosing Turkey, and that he, like all other Turkish players, viewed the Turkish national football team's jersey as a symbol of "national glory." In the same context, he made it plain that he would never comment on any of his colleagues' (meaning Özil's) decisions to play for the country they lived in. In later articles, he repeatedly emphasized the fact that he felt both Turkish and German, which, however, saw minimal response in the Turkish public sphere.

Özil was again asked to justify his decision to play for Germany during the press conference before the match. He explained that he was a positive example of integration and that young people in Germany view him as a role model. In Turkey, the topic of Şahin and Özil lost all salience with the defeat against Germany, and the fact that Özil was booed throughout the whole match was only addressed in passing. Mehmet Yilmaz, editor of Hürriyet, drew attention to this fact when he identified some ambivalence in this collective behavior: before the match, Turkish people were proud of this "fantastic Turkish guy," due to his world class performances at the World Cup 2010, but now, when he played against the Turkish national football team, he was suddenly depicted as a "bad boy" and an "ethnic traitor" (Hürriyet, October 10, 2010).

\section{Discussion}

In this article, we pose the question of how debates over belonging evolve around national football team diversity in Germany and Turkey, and whether these debates transform across time and space. Essentially, our research centers around a major question: do such debates over belonging in international football challenge established narratives of national belonging? If so, how? The debates revolving around Mesut Özil and Nuri Şahin in German and Turkish newspapers notably emerged as debates over (trans-)national belonging. Our analysis elucidates three results that arise in the context of these games of belonging.

First of all, in light of an approaching international football event, games of belonging are introduced. These events may consist of either international football matches or popular football players' upcoming announcements to play for one or other national football team. In most cases, 
both the players' decision-making processes, their ultimate choices, and international football trigger contentious debates on national belonging in national public spheres. It also becomes apparent in this case that some relevant German-Turkish football events made it into one nation's public agenda, but not into the other's.

These international football events (matches or players' decisions) serve as a necessary condition for games of belonging to occur, but they are insufficient in terms of causing them. Instead, national discursive opportunity structures in immigrant integration politics intervene. Hence, games of belonging emerge at the intersection of international football events and performances supportive of the national immigration and integration discourse. For instance, when Şahin chose to play for the Turkish national team, the German public refrained from questioning his decision as a backlash to the liberal immigrant integration path German politics had taken; he was far from being blamed for turning his back on Germany. Since Germany opted for a liberal immigration country status and citizenship laws, debates over belonging were largely tamed. In this tamed context, the emergence of a ethnoculturally restrictive game of belonging was blocked.

Second, after games of belonging were highlighted, related international football and public actors involved themselves. We observed a major continuity across time and space that frames such involvement. Media, politicians, and national team officials urged the subjects of these debates, Özil and Şahin, to express their emotional attachments and make declarations of loyalty to one or the other nation, and thereby recognize their roles as representatives of national bodies. These actors interpreted national belonging as a zero-sum game: the more one belongs to nation $\mathrm{A}$, the less s/he belongs to nation $\mathrm{B}$.

As such, international football institutions such as Fédération Internationale de Football Association (FIFA) and Union of European Football Associations (UEFA) cater to binary expectations in the public as they build on nationalism (see for example Giulianotti and Robertson 2004). For example, international football regulations clearly prohibit joining more than one football national team and expect formal requirements, such as citizenship, that prove legal belonging to a nation.

Beyond that, debates on national football teams revolve around the self-representation of a nation (Huhn and Metzger 2016; Ismer 2011; Markovits and Rensmann 2007; Meier and Leinwather 2013). Nations (re-)affirm their cultural identity through national football teams, among others. As stated above, the empirical findings resemble both nations' belonging contexts: while Germany transformed itself from being a self-declared "non-immigration country" with a largely restrictive concept of ethnocultural belonging fixed to a more civic understanding of nationhood (Bloemraad, Korteweg, and Yurdakul 2008; Brubaker 1992; for respective citizenship law transformation, see Faist and Triadafilopoulous 2006), Turkey clearly based belonging on ethnocultural elements, with a Sunni Muslim Turkish ethnic identity on the rise, which also applies to the Turkish diaspora abroad (see Aydin 2014).

Although Özil was still perceived as an ethnic Turk, he was stripped of being recognized as a "proper Turk" (and was thus an "ethnic traitor") among Turks living in either Germany or Turkey. As mentioned earlier, boundary-crossing was not accompanied by the loss of his entire Turkish ethnicity in the Turkish perception. Özil remains a "defected Turk," in that he is ethnically a Turk, but culturally he does not fully belong anymore. The strength of the rigid Turkish ethnocultural boundary is even more visible in the case of Şahin, who is constantly asked to emotionally perform Turkish ethnocultural identity. Evidently, the gurbetçi discourse plays a significant excluding role in the question of his belonging. Ultimately we can conclude that, in the Turkish context, the players in games of belonging are expected to perform ethnocultural Turkish identity in order to be recognized as full members of Turkish society. These slightly different national structures of awarding less-than-full or, at times, full membership to others lack the inclusion of a crucial dimension to understand how national belonging is challenged, which has been the role attached to the subject performances.

Third, if there is an ongoing game of belonging, the actors subjected to it are sooner or later asked to participate in a public debate. Hence, when the subjects of such debates become active 
participants, they rejected this zero-sum game of national belonging. Instead, they claimed to have chosen one nation over the other in international football because there was no alternative. Yet, they emphasize that this football-related decision does not fairly represent their feelings of belonging to both Germany and Turkey equally, that is, their "multiple belonging" as a counterpart to rigid narratives of national belonging (Foroutan 2010; Hall 2002). This was the case when, for instance, Özil stated he would prefer to play for both national football teams if international football introduced such a regulation. Because of that, we argue that mono-national belonging as a concept fizzles out when expected to sufficiently grasp football players' projections of collective belonging. Hence, we interpret the wish to play for both national teams (and their respective justifications) as a vanguard expression of collective belonging that transcends the monolithic ethnocultural framework and boundaries of the nation.

In their comparative study of headscarf debates in Germany, France, the Netherlands, and Turkey, Korteweg and Yurdakul (2014) similarly illustrate that periods of contention mark a necessary condition for alternative understandings of national belonging to be publicly voiced by the subjects of those debates. Thus, games of belonging display opportunity structures for alternative narratives of belonging, multiethnic, national, or simply transnational, to be voiced publicly. Here, we identify a periodic self-questioning of collective identities through games of belonging in societies of migration and in the transnational spaces between sending and receiving countries which result in preserving or transforming established boundaries.

German politics, and to some extent national team officials, aimed to foster immigrant integration into "German society" by reinforcing Özil's decision, especially in a period of sporting success. The symbolic handshake with German chancellor Merkel seemed to be an act of granting Özil full membership in German society, after being, hitherto, a less-than-full member of German society as a German citizen with a Turkish background.

While this article contributes to the immigrant integration and international football literature, it leaves the reader with two blind spots, which should guide future research in this field. First, gender has been omitted, as we encountered almost no explicitly gendered expressions in the empirical data. However, the coverage of different empirical data might help future research overcome this issue. We believe that visual media analysis would especially capture gendered expressions of belonging on and off the field. For instance, Granit Xhaka and Xherdan Shaqiri performed such gendered expression when they scored against the Serbian football national team while playing for the Swiss team in the 2018 FIFA World Championship. They flexed their strong muscles and, with their hands, they formed the bicephalous eagle represented on the Republic of Albania's flag. This case of Swiss national team players performing Albanian ethno-nationalism endorses a relatively clear expression of masculine (ethno-)national identity performances. Future research should definitely focus on such instances of gender and (trans-)national belonging in international football.

Second, this article merely covers the "golden age" of the German football national team after Joachim Löw took over as head coach in 2006 and succeeded in the 2014 World Championship. The recent 2018 World Cup can serve as a valuable comparison, as the diverse German national team performed poorly. On July 22, 2018, Özil resigned from the German national team in response to the intense questioning of his belonging to Germany. In a written public statement, he lamented racist attacks by the media and national team officials against him during the World Cup after a picture of him and Ilkay Gündoğan with the Turkish President Erdoğan had been released ahead of the Turkish presidential elections (for authoritarian leaders' diaspora embracement politics, see Glasius 2018). In his reaction, Özil sides with French Karim Benzema and Belgian Romelu Lukaku when stating that German natives viewed him as German in times of success (the handshake with Merkel, when Özil was awarded two integration prizes, etc.), but when the national team performs poorly, he is portrayed as an immigrant. It is worth noting that the economization of national football team ethnic diversity has serious potential for possible future backlashes. As the French case of the late 1990s and the recent German case of the 2018 FIFA World Cup indicate, if ethnic diversity is discursively linked to athletic success by established public actors, it is likely to be 
connected to failures as well. Cross-national comparisons of Western European diverse national football teams' successes and failures might inform the results explored in this study of the GermanTurkish case. Of course, such future investigations should not merely compare natives and newcomers; instead, it seems that some ethnicities, races, or religions are more likely than others to be othered in contemporary Western Europe.

In toto, international football has become an area of contentious games of belonging, not only for football players, but also for the societies involved. In such scenarios, narratives of national belonging are voiced and challenged, which reverberate emotional reactions in the media and wider public. And, as the debates around the 2018 World Cup show, stories of national belonging in international football (will) go on.

Acknowledgments. We are grateful to Gökçe Yurdakul and Bernhard Forchtner for their comments on earlier versions. We are also thankful to panelists of our presentation at the ASN 2016 World Convention at the Columbia University, NYC, who commented on our manuscript. All mistakes remain our own.

Financial Support. Stefan Metzger's work was supported by a scholarship of the Heinrich-Böll-Foundation, Berlin.

Disclosure. Authors have nothing to disclose.

\section{Notes}

1 In March 2016 the conflict reached a climax. Due to a court decision, the police entered the Zaman headquarters, and since then the daily newspaper has been appropriated by the Turkish state.

2 The football players' perspectives include, of course, Mesut Özil and Nuri Sahin. In addition to them, we also coded statements from their close relatives and managers, and at one point we coded statements of other football players with a Turkish background in Germany if their claims were related to the topic under scrutiny. This approach was essential to our sampling strategy.

3 The raw data for the media discourse analysis are available from the authors upon request.

4 The term might be compared to the German Exildeutsche, but it is different in its cultural meaning. In Germany, the term Exildeutsche is somewhat semantically linked to ethnic Germans who went into exile due to political persecution, whereas in Turkey, gurbetçi has a broader meaning, though it is semantically based on the migration flow of Turkish guest workers. Though this term is a general one for Turks living abroad, it still does not cover the göçmen, who are descendants of the Ottoman Empire in Eastern Europe, which later returned to Turkey.

\section{References}

Abell, Jackie, Susan Condor, Stephen Gibson, Rob Lowe, and Clifford Stevenson. 2007. "Who Ate All the Pride? Patriotic Sentiment and English National Football Support." Nations and Nationalism 13 (1): 97-116.

Adamson, Fiona. 2001. "Mobilizing for the Transformation of Home: Political Identities and Transnational Practices." In New Approaches to Migration? Transnational Communities and the Transformation of Home, edited by Nadje Al-Ali and Khalid Koser, 155-168. London: Taylor and Francis.

Alba, Richard. 2005. "Bright vs. Blurred Boundaries: Second-Generation Assimilation and Exclusion in France, Germany, and the United States." Ethnic and Racial Studies 28 (1): 20-49.

Altunışık, Meliha Benli, and Özlem Tür. 2005. Turkey: Challenges of Continuity and Change. London: Routledge.

Anderson, Benedict. 1991. Imagined Communities: Reflections on the Origin and Spread of Nationalism. London: Verso.

Aydin, Yaşar. 2014. "The New Turkish Diaspora Policy. Its Aims, Their Limits and the Challenges for Associations of People of Turkish Origin and Decision-Makers in Germany.” SWP Research Paper, RP 10. Berlin, Stiftung Wissenschaft und Politik.

Bade, Klaus J., and Jochen Oltmer. 2004. Normalfall Migration. Deutschland im 20. und frühen 21. Jahrhundert. Bonn: Bundeszentrale für politische Bildung.

Bartolini, Stefano. 1993. “On Time and Comparative Research.” Journal of Theoretical Politics 5 (2): 131-167.

Barth, Fredrik. 1969. Ethnic Groups and Boundaries: The Social Organization of Cultural Difference. London: Waveland Press. Beck, Ulrich, and Edgar Grande. 2007. Cosmopolitan Europe. Cambridge, UK: Polity Press.

Bail, Christopher A. 2008. The Configuration of Symbolic Boundaries against Immigrants in Europe. American Sociological Review 73 (1): 37-59. 
Blecking, Diethelm. 2006. "Vom Polackenklub zu Türkiyem Spor - Migranten und Fußball im Ruhrgebiet.” In Zur Sozial- und Kulturgeschichte des Fußballs, edited by Beatrix Bouvier, 183-199. Trier: Friedrich-Ebert-Stiftung.

Bloemraad, Irene, Anna Korteweg, and Gökçe Yurdakul. 2008. "Citizenship and Immigration: Assimilation, Multiculturalism and the Challenges to the Nation State." Annual Review of Sociology 34: 153-180.

Boli, Claude, Yvan Gasaut, and Fabrice Grognet, eds. 2010. Allez la France! Football et immigration. Paris: Gallimard.

Bora, Tanil. 2008. "Einer von uns.” Ballester 34. http://www.ballesterer.at/heft/thema/einer-von-uns.html. (Accessed March 27, 2017.)

Brubaker, Rogers. 1992. Citizenship and Nationhood in France and Germany. Cambridge, MA: Harvard University Press.

Brubaker, Rogers. 2010. "The Return of Assimilation? Changing Perspectives on Immigration and Its Sequels in France, Germany, and the United States." Ethnic and Racial Studies 24 (4): 531-548.

Castles, Stephen, and Mark J. Miller. 1998. The Age of Migration: International Population Movements in the Modern World. Houndmills, Basingstoke, UK: Macmillan Publishers Limited.

Çinar, Alev, and Hakki Taş. 2017. "Politics of Nationhood and the Displacement of the Founding Moment: Contending Histories of the Turkish Nation." Comparative Studies in Society and History 59 (3): 657-689.

Eder, Klaus. 2006. "Europe's Borders: The Narrative Construction of the Boundaries of Europe." European Journal of Social Theory 9 (2): 255-271.

Faist, Thomas. 2000. The Volume and Dynamics of International Migration and Transnational Social Spaces. Oxford/New York: Clarendon Press/Oxford University Press.

Faist, Thomas, and Phil Triadafilopoulos. 2006. "Beyond Nationhood: Citizenship Politics in Germany since Unification." Working Paper No. 1. Toronto: University of Toronto, Munk Centre for International Studies.

Foroutan, Naika. 2010. "Neue Deutsche, Postmigranten und Bindungs-Identitäten. Wer gehört zum neuen Deutschland?" Aus Politik und Zeitgeschehen 46-47: 9-15.

Fox, Jon, and Cynthia Miller-Idriss. 2008. "Everyday Nationhood.” Ethnicities 8 (4): 536-576.

Glasius, Marlies. 2018. "Extraterritorial Authoritarian Practices: A Framework.” Globalizations 15 (2): 179-197.

Glick-Schiller, Nina, Linda Basch, and Cristina Blanc-Szanton. 1992. Towards a Transnational Perspective on Migration. Race, Class, Ethnicity and Nationalism Reconsidered. New York: New York Academy of Sciences.

Giulianotti, Richard. 1999. Football: A Sociology of the Global Game. Cambridge, UK: Polity Press.

Giulianotti, Richard and Roland, Robertson. 2004. "The Globalization of Football: A Study in the Glocalization of the 'Serious Life." The British Journal of Sociology 55 (4): 545-568.

Hall, Peter A., and Michèle Lamont. 2013. "Why Social Relations Matter for Politics and Successful Societies." Annual Review of Political Science 16: 49-71.

Hall, Stuart. 2002. "Political Belonging in a world of Multiple Identities." In Conceiving Cosmopolitanism: Theory, Context and Practice, edited by Steven Vertovec and Robin Cohen, 25-31. Oxford, UK: Oxford University Press.

Hobsbawm, Eric, and Terence Ranger. 1992. The Invention of Tradition. Cambridge, UK: Cambridge University Press.

Houlihan, Barrie. 1997. "Sport, National Identity and Public Policy.” Nations and Nationalism 3 (1): 113-137.

Huhn, Daniel. 2015. “Más Integración? Vom Wert und Umgang mit einer multikulturellen Fußballnationalmannschaft.” In Die Geschichte von Fußball und Migration im Ruhrgebiet. Begleitbuch zur Ausstellung. Von Kuzorra bis Özil, edited by LWLIndustriemuseum and Dietmar Osses, 117-126. Essen: Klartext-Verlag.

Huhn, Daniel, and Stefan Metzger. 2016. "Von Kuzorra bis Özil. Der Ruhrgebietsfußball als Aushandlungsort von Zugehörigkeit.” Lendemains 41 (161): 38-50.

Huntington, Samuel. 2004. Who Are We? The Challenge to America's National Identity. New York: Simon \& Schuster.

Ismer, Sven. 2011. "Embodying the Nation: Football, Emotions and the Construction of the Collective Identity." Nationalities Papers 39 (4): 547-565.

Kaya, Ayhan. 2014. Türkiye’de Göç ve Uyum Tartışmaları: Geçmişe Dönük Bir Bakış.” Idealkent 14: 11-28.

Korteweg, Anna, and Gökçe Yurdakul. 2009. "Islam, Gender and Immigrant Integration: Boundary Drawing in Discourses on Honour Killing in the Netherlands and Germany." Ethnic and Racial Studies 32 (2): 218-238.

Korteweg, Anna, and Gökçe Yurdakul. 2014. The Headscarf Debates: Conflicts of National Belonging. Stanford, CA: Stanford University Press.

Lamont, Michèle, and Virág Molnár. 2002. “The Study of Social Boundaries in the Social Sciences.” Annual Review of Sociology 28 (1): 167-195.

Markovits, Andrei S., and Lars Rensmann. 2007. Querpass. Sport und Politik in Europa und den USA. Göttingen: Die Werkstatt.

Mandel, Ruth. 2008. Cosmopolitan Anxieties: Turkish Challenges to Citizenship and Belonging in Germany. Durham, NC: Duke University Press.

Martin, Philipp L. 2004. “Germany: Managing Migration in the 21st Century: A Global Perspective." In Controlling Immigration, edited by Wayne A. Cornelius, Takeyuki Tsuda, Philipp L. Martin, and James F. Hollifield, 221-252. Stanford, CA: Stanford University Press.

Meier, Henk Erik, and Marcel Leinwather. 2013. "Finally a 'Taste of Diversity'? National Identity, Consumer Discrimination, and the Multi-Ethnic German National Football Team.” European Sociological Review 29 (6): 1201-1213.

Metzger, Stefan. 2018. Das Spiel um Anerkennung. Fußballvereine mit Türkeibezug im Berliner Amateurfußball. Reihe: Studien zur Migrations- und Integrationspolitik. Wiesbaden: Springer VS Verlag. 
Özvatan, Özgür, and Bernhard Forchtner. 2019. “The Far-Right Alternative für Deutschland in Germany: Towards a 'Happy Ending'?" In The New Auhtoritarianism: Vol. 2: A Risk Analysis of the European Alt-Right Phenomenon, edited by Alan Waring. Hannover: ibidem Press.

Reisigl, Martin, and Ruth Wodak. 2009. “The Discourse-Historical Approach.” In Methods of Critical Discourse Analysis, 2nd ed., edited by Ruth Wodak and Michael Meyer, 87-121. London: Sage.

Sicakkan, Hakan G. 2012. "Diversity, Polity, and the European Public Sphere.” Javnost - The Public 19 (1): 5-17.

Soysal, Yasemin N. 2000. “Citizenship and Identity: Living in Diasporas in Post-War Europe?” Ethnic and Racial Studies 23 (1): $1-15$.

Sugden, John, and Alan Tomlinson. 1998. "Power and Resistance in the Governance of World Football: Theorizing FIFA's Transnational Impact.” Journal of Sport and Social Issues 22 (3): 299-316.

Tarrow, Sidney. 2013. Contentious Politics. Oxford, UK: Oxford University Press.

Thränhardt, Dietrich. 1995. "Germany: An Undeclared Immigration Country.” New Community 21 (1): 19-36.

Tilly, Charles. 2008. Contentious Performances. Cambridge Studies in Contentious Politics. Cambridge, UK: Cambridge University Press.

Wimmer, Andreas. 2008. “Elementary Strategies of Ethnic Boundary Making.” Ethnic and Racial Studies 31 (6): $1025-1055$.

Wodak, Ruth. 2013. Critical Discourse Analysis. Los Angeles: Sage.

Wodak, Ruth, and Michael, Meyer, eds. 2009. Methods of Critical Discourse Analysis. London, SAGE.

Yurdakul, Gökçe. 2009. From Guest Workers into Muslims: The Transformation of Turkish Immigrant Associations in Germany. Newcastle-upon-Tyne, UK: Cambridge Scholars Publishing.

Yuval-Davis, Nira. 2011. The Politics of Belonging: Intersectional Contestations. London: Sage.

Cite this article: Metzger, S. and Özvatan, Ö. 2020. Games of Belonging: Football, Boundaries and Politics between Germany and Turkey. Nationalities Papers 48: 737-751, doi:10.1017/nps.2019.4 